\title{
Coastal inundation multi-hazard analysis for a construction site in Malaysia
}

\section{Carl B. Harbitz*, Gunilla Kaiser, Sylfest Glimsdal and Christian Jaedicke}

Norwegian Geotechnical Institute, P.O. Box 3930 Ullevål Stadion, N-0806 OSLO, Norway

Email: carl.bonnevie.harbitz@ngi.no

Email: gunilla.kaiser@ngi.no

Email: sylfest.glimsdal@ngi.no

Email: christian.jaedicke@ngi.no

*Corresponding author

\section{Athanasios T. Vafeidis}

Coastal Risks and Sea-Level Rise Research Group,

Institute of Geography ‘The Future Ocean' Excellence Cluster,

Christian-Albrechts University Kiel,

Ludewig-Meyn-Str. 14, 24098 Kiel, Germany

Email: vafeidis@geographie.uni-kiel.de

\section{Stephan E. Göthlich}

Robert Bosch $\mathrm{GmbH}$,

Lorenzstraße 7-9, 70435 Stuttgart-Zuffenhausen, Germany

Email: Stephan.Goethlich@bosch.com

\section{Øyvind Armand Høydal, Finn Løvholt and Farrokh Nadim}

Norwegian Geotechnical Institute,

P.O. Box 3930 Ullevål Stadion,

N-0806 OSLO, Norway

Email: oyvind.armand.hoydal@ngi.no

Email: finn.lovholt@ngi.no

Email: farrokh.nadim@ngi.no

\begin{abstract}
Coastal inundation due to multiple hazards was analysed for a potential manufacturing plant at the Batu Kawan Industrial Park in Penang state, Malaysia. The analysis accounted for river floods, rainfall and flash floods, cyclones, tides, storm surges, sea-level rise, and tsunamis. Earthquakes, volcanoes, and the effects of climate changes were also briefly evaluated. The proposed site elevation of $2.60 \mathrm{~m}$ LSD (land survey data level; $30 \mathrm{~cm}$ above mean sea level) will probably be reached by both the 100 -year flood and the
\end{abstract}


100-year combined tide and storm surge. The flooding risk is low, but coincidence with storm surge or high tide will aggravate the situation. Sea level rise over the next 100 years is assumed less than $0.55 \mathrm{~m}$. The relative level for the other hazards was found to be lower. A further comparison of the various hazard levels is not meaningful without considering also the consequences (i.e., the risk).

Keywords: multi-hazard analysis; manufacturing site; flood; cyclone; tide; storm surge; sea-level rise; SLR; tsunami; earthquake; volcano; Penang State, Malaysia.

Reference to this paper should be made as follows: Harbitz, C.B., Kaiser, G., Glimsdal. S., Jaedicke, C., Vafeidis, A.T., Göthlich, S.E., Høydal, Ø.A., Løvholt, F. and Nadim, F. (2016) 'Coastal inundation multi-hazard analysis for a construction site in Malaysia', Int. J. Risk Assessment and Management, Vol. 19, Nos. 1/2, pp.142-164.

Biographical notes: Carl B. Harbitz is an Expert Adviser at NGI Oslo, Division of Natural Hazards. He also holds a position as an Adjunct Professor in the Department of Mathematics at the University of Oslo. His research interests include wave mechanics and tsunamis, dynamics of submarine and subaerial landslides, numerical analysis, as well as hazard, vulnerability, and risk analysis. $\mathrm{He}$ received his $\mathrm{MSc}$ and $\mathrm{PhD}$ in Fluid Mechanics from University of Oslo, Department of Mathematics.

Gunilla Kaiser is a Physical Geographer and a Senior Researcher at NGI Oslo, Division of Natural Hazards. Her research interests are coastal floods, including hazard, vulnerability, and risk analysis. She received her Diploma and PhD in Physical Geography from the University of Kiel.

Sylfest Glimsdal is a Senior Engineer at NGI Oslo, Division of Natural Hazards. His research interests include wave mechanics and tsunamis, with a special attention to numerical modelling of generation, propagation, and run-up of tsunamis. He holds an MSc and a PhD in Fluid Mechanics from University of Oslo, Department of Mathematics.

Christian Jaedicke is a Technical Lead Avalanches at NGI Oslo, Division of Natural Hazards. His research interests include meteorological hazards such as snow avalanches, landslides, and floods, as well as early warning, vulnerability, and risk analysis. He holds an MSc in Hydrology from Uppsala University. He holds a $\mathrm{PhD}$ in Arctic Meteorology from University of Bergen/University Center on Svalbard.

Athanasios T. Vafeidis holds a position as a Professor in Coastal Systems and Hazards at Christian-Albrechts University Kiel, Institute of Geography. His research focuses on assessing climate-change induced impacts in coastal regions and on understanding how coastal systems respond to combined pressure from natural and anthropogenic forcings. He holds a MEng in Surveying Engineering from the National Technical University of Athens and a MSc and PhD in Physical Geography from King's College London.

Stephan E. Göthlich holds a Master's degree (Diploma) in Economics and Business Administration. In his $\mathrm{PhD}$ thesis, he analysed the emergence of collaborative business ecosystems. He has more than ten years' experience from business life. While in his position as business developer at Bosch Solar Energy AG he was responsible for global scouting for manufacturing sites. Currently, he is focusing on applying game theory approaches on negotiations and risk analysis in global sourcing processes (for Robert Bosch $\mathrm{GmbH}$ ). 
Øyvind Armand Høydal is a Senior Engineer at NGI Oslo, Division of Natural Hazards. He does consulting related to natural hazards including floods, debris flows, snow avalanches, landslides, and geotechnical stability by field assessment as well as numerical analyses. In recent years, effects of forests and forestry on natural hazards have been studied. He holds an MSc in Applied Geophysics and Geology from the Norwegian University of Science and Technology, Department of Geology.

Finn Løvholt is a Senior Engineer in the Division of Offshore Energy at NGI Oslo. He also holds a position as an Adjunct Associate Professor in the Department of Mathematics at the University of Oslo. He has extensive experience related to modelling hazard and risk due to earthquake and landslide tsunamis as well as dynamics of geo-materials. He received his MSc at the Norwegian Agricultural University in 1998 on the topic of unsaturated ground water flow. He received his $\mathrm{PhD}$ in Fluid Mechanics from the Department of Mathematics at the University of Olso.

Farrokh Nadim is the Technical Director at NGI Oslo. He was the Director of NGIs Centre of Excellence, International Centre for Geohazards (ICG) 2003-2012. He has experience with research, consulting, and university teaching. His areas of expertise include geotechnical earthquake engineering, offshore foundation design, dynamic soil behaviour, geohazards risk assessment, and risk management.

\section{Introduction}

\subsection{Motivation and background}

Selecting suitable sites for buildings and infrastructure is a fundamental process in both business-related and governmental activities. In the USA the authorities have codified and published universal site selection processes for these purposes (e.g., GSA - US General Services Administration, 2015). These processes date back to the 1950s for large governmental projects such as Los Alamos and the Air Force Academy, and have been continuously improved since then. Today, many corporations in the private sector follow these or similar methodologies, which have also found their way into standard business textbooks (e.g., Peiser and Frej, 2003).

A rigorous site selection process is vital in the high-technology industries, such as semiconductors or photovoltaics, because the capital required to build new factories has grown dramatically over the years. The cost of a typical high-technology factory today is in the order of several billion USD (Christensen et al., 2008; Samsung, 2011).

With so much capital at stake, a detailed risk assessment for potential manufacturing sites is a must. Indeed, the universal site selection processes recommend the consideration of risks related to earthquakes and floods. However, a systematic integration of several sources of risk in a multi-risk analysis has not yet been emphasised. In contrast to single-risk analyses, the examination of multiple risks poses a range of additional challenges due to the differing characteristics of hazards and their interactions.

In this paper, the search for a new manufacturing site for Bosch Solar Energy AG, a photovoltaics manufacturer and subsidiary company of the German industrial conglomerate Bosch, is presented. To better meet the needs of the local customers, the 
company decided to build a manufacturing hub located in Asia. The envisaged capital expenditures were projected to be the largest investment in the history of the company. The site selection process started in late 2010 and quickly narrowed down to a few eligible sites in Malaysia and China, with Batu Kawan Industrial Park in Penang state, Malaysia, being the most favourable one (Figure 1). However, after the March 2011 Tohoku earthquake and tsunami event, which caused the Fukushima disaster, the company decided to perform a thorough multi-hazard assessment for the chosen site, going beyond and extending their standard site selection procedures.

Since the study site is exposed to several types of natural hazards, some of which are correlated and interacting, there is a need for a multi-hazard approach to consider the interactions and possible cascading effects. Multi-hazard is a wide concept that, in its most general interpretation, can be defined as "the process to determine the probability of occurrence of different hazards, either occurring at the same time or shortly following each other, because they are dependent upon one another or because they are caused by the same triggering event or hazard, or merely threaten the same elements at risk without chronological coincidence" (European Commission, 2010). Following this definition, multi-hazard analysis comprises both the process of analysing different (independent) hazards threatening a given (common) area, and the process of analysing possible interactions and/or cascade effects among the different types of hazardous events.

Looking at the current state-of-the-art of multi-hazard practices (with focus on natural hazards), Garcia-Aristizabal et al. (2012) found that most of the currently available multi-hazard applications assess independent hazards threatening common exposed elements, and that few efforts have been dedicated to the definition and quantification of cases where there are possible interactions and cascade effects among the different hazardous events. Multi-hazard analysis as part of natural risk assessment is further discussed by Bell and Glade (2004), while a framework for quantitative multi-risk analysis of natural hazards is described by Schmidt et al. (2011). Kappes et al. (2012) review the challenges related to multi-hazard risk analysis. A case study assessing risks related to storms, floods, and earthquakes for the city of Cologne is performed by Grünthal et al. (2006). An example of a case study focusing solely on coastal hazards and risks is presented for Sri Lanka by Garcin et al. (2008). Finally, it should be mentioned that cascade effects, including the identification of possible cascade events for different space-time scales, are among the ambitious objectives of the MATRIX project (http://matrix.gpi.kit.edu), a multi-national research project funded by the European Commission's 7th Framework Program (FP7).

\subsection{Objectives and elements of the multi-hazard analysis}

The manufacturing site considered in this study is located in the centre of the Asian tropics at $5^{\circ} 13^{\prime} \mathrm{N}$. The climate is characterised by a stable temperature throughout the year with highs just above $32^{\circ} \mathrm{C}$ and lows around $23^{\circ} \mathrm{C}$. The area is naturally flat and low-lying close to the shore, and potentially exposed to flooding and tsunamis. The main objective of the present analysis was to apply a unified approach for screening of multiple coastal hazards threatening a common area, rather than detailed studies of single hazards. Norwegian Geotechnical Institute (NGI) Oslo together with the Coastal Risks and Sea level Rise Research Group of the Future Ocean Excellence Cluster, Department of Geography, Christian-Albrechts Universität zu Kiel (CAU), Germany, performed the multi-hazard analysis for the site. The study comprised exposure to: 
1 river floods, rainfall and flash floods

2 tides, cyclones, storm surges, and sea-level rise (SLR)

3 earthquake- or landslide-induced tsunamis

4 the largest credible combined flooding scenario (tsunami - storm surge river/rainfall flooding) for the manufacturing site.

Natural hazards not directly related to inundation, such as earthquakes and volcanoes, were also briefly considered. Some of the hazards discussed are correlated. For example, tropical cyclones cause storm surge and flooding, while tsunamis are correlated with earthquakes or volcano flank collapses and eruptions. Hence, the combined effects of tides and storm surges and the cascading effects of earthquakes and tsunamis were considered in a multi-hazard context. However, independent extreme events, such as tropical cyclones and earthquakes, were considered separately. The study was based on multiple sources of information, such as peer-reviewed journal papers, third-party reports, review of historic events, previous work by NGI, as well as new site-specific calculations.

The individual hazard components were considered for several return periods depending on the information available. Typically, codes for design of infrastructure require a return period of 100-200 years for the design flood event. For example, the Norwegian regulations for roads and railroads specify a design return period of 200 years with regard to flooding and drainage (NGI, 2014a). Hence, a design return period of 100-200 years was applied for the coastal inundation multi-hazard analysis.

Figure 1 The Batu Kawan site and surrounding areas (see online version for colours)

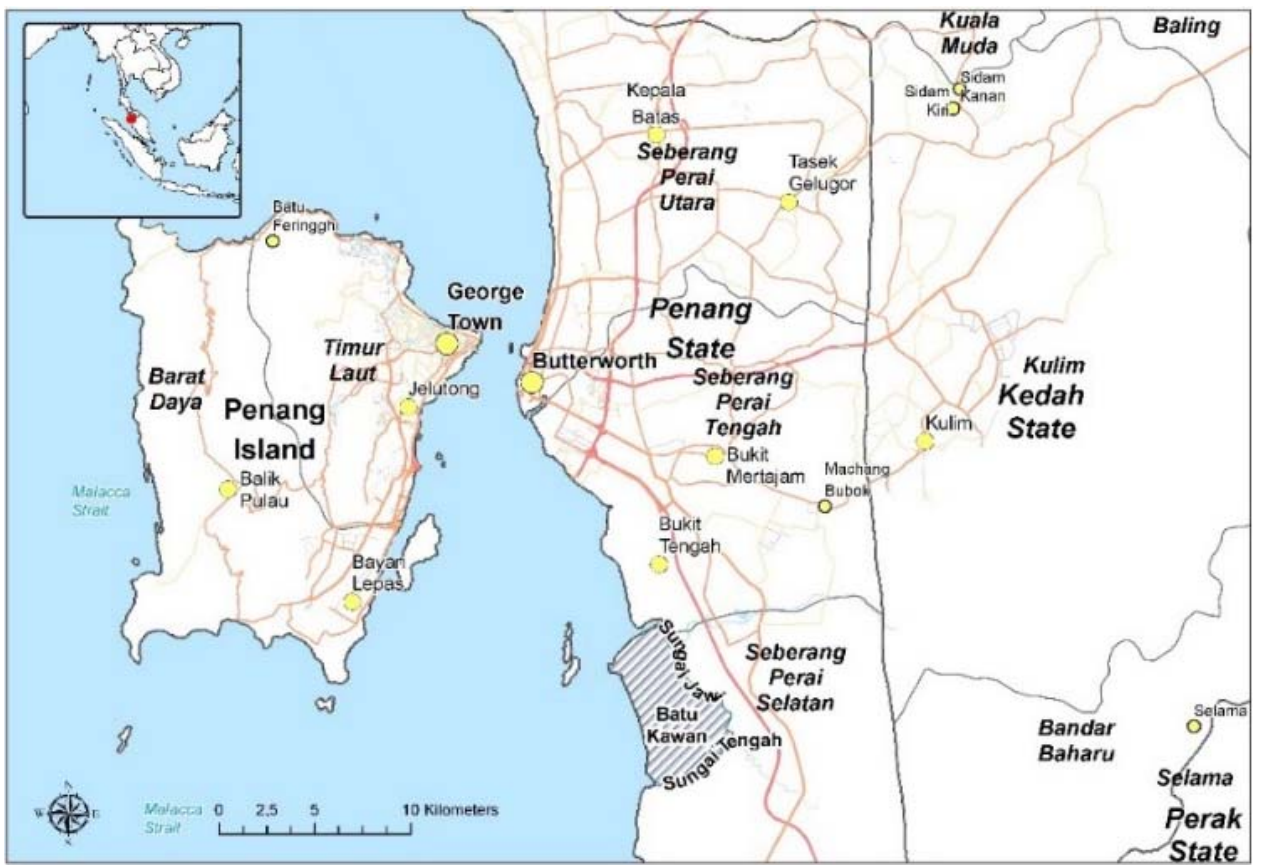


In the following sections, the historical observations and relevant previous studies are reviewed before the results of the present analysis are presented for each individual hazard component. Finally, the results for the various hazards are compared in a separate section on the multi-hazard analysis.

\section{River floods, rainfall and flash floods}

The annual precipitation in the area of the proposed site is 2,530 $\mathrm{mm}$ (Bayan Lepas Airport, $20 \mathrm{~km}$ west of the site). There are two distinct precipitation maxima each year, in April/May and September/October (Figure 2). Flash floods (rapid flooding of low-lying areas distinguished from a regular flood by a timescale of less than six hours) and floods are common phenomena in the wet season. Short time, high intensity rainfalls do not normally represent any problem for infrastructure and population as long as the natural terrain is able to absorb the precipitation. In urban or cultivated areas, drainage systems have to be in place to account for the reduced infiltration and retention ability of paved and bare surfaces. The major flood events record for Malaysia starts in 1926, and continues with events in 1931, 1947,1954, 1957, 1963, 1965, 1067, 1969, 1971, 1973, 1979, 1983, 1988, 1993, 1998, 2001, 2004, 2006, and 2007 (Government of Malaysia Department of Irrigation and Drainage, 2009). Selected events are presented in Table 1. The most prominent event is the 1971 flash flood in Kuala Lumpur where 32 people were killed and 180000 affected. In the Penang state, floods occurred at least in 2003, 2007, 2008, 2010, and most recently on 30 April 2011 (Googlenews). These events mostly affected urban areas, where the drainage system is not able to manage the short time rainfall. In 2007 flash floods affected the northern part of Batu Kawan (New Straits Times, 2007). Also in 2003, a larger flood was reported, but flooding of Batu Kawan was not documented (Jurutera Perunding Consulting Engineers, 2008).

Flash floods and intensive rainfalls can occur annually on Batu Kawan. Figure 3 shows an intensity-duration-frequency (IDF) plot of precipitation records adopted for Batu Kawan. Intensities of more than $70 \mathrm{~mm} /$ hour within 60 minutes duration can be expected every second year and the 50 -year event amounts to $120 \mathrm{~mm} /$ hour within 60 minutes. The maximum monthly recorded precipitation was $680 \mathrm{~mm}$ in October 2003 on 15 days with recorded rainfall. This event most likely caused the flooding on the Sungai Jawi River banks reported earlier.

River floods, rainfall and flash floods must be analysed with regard to impact in an industrialised area, and with regard to design of drainage systems. A drainage system designed for the agricultural use of the site is currently in place. This system will need a major upgrade before any industrial development can be realised. Studies by Roseli (1999) show that land-use changes from agriculture to urban areas may double the runoff. The most severe flooding situations in lowland coastal areas such as Batu Kawan can occur for a combination of storm surge, high tide, and intense rainfalls. Also these effects can to some degree be managed by a well-engineered drainage system. 
Figure 2 Climate chart of the weather station Bayan Lepas airport, $20 \mathrm{~km}$ west of the Batu Kawan site, showing monthly minimum and maximum air temperature as well as mean precipitation for the period 2000-2010 (see online version for colours)



Table 1 Selected flash floods in Malaysia

\begin{tabular}{ll}
\hline Date & Location \\
\hline 04 Jan 1971 & Kuala Lumpur hit by flash floods \\
1997 & Kedah, Terengganu \\
1999 & Pulau Pinang, Perak Perak \\
2000 & Terengganu, Kelantan \\
2001 & Pahang, Johor \\
2002 & Kuala Lumpur \\
2003 & Kuala Lumpur, Pulau Pinang, Kedah \\
2004 & Kelantan, Terengganu, Pahang \\
2005 & Kedah, Kelantan, Terengganu \\
02 Mar 2006 & Shah Alam hit by flash floods \\
19 Dec 2006 & $\begin{array}{l}\text { Several parts of Johor state including Muar, Johor Bahru, Skudai and Segamat } \\
\text { were hit by flash floods }\end{array}$ \\
10 Jan 2007 & Several parts of Johor state were hit by flash floods again \\
10 Jun 2007 & $\begin{array}{l}\text { Kuala Lumpur hit by flash floods, worst since 10 June 2003 } \\
\text { Dec 2007 }\end{array}$ \\
$\begin{array}{l}\text { Several parts of East Coast of peninsula including Kelantan, Terengganu, } \\
\text { Pahang and Johor were hit by flash floods }\end{array}$ \\
Nov 2010 & Kedah and Perlis flooded due to heavy rainfall after a tropical depression \\
\hline
\end{tabular}

Source: Data collected from Government of Malaysia Department of Irrigation and Drainage Malaysia $(2009,2011)$ 
Figure 3 IDF curves showing rainfall intensities ( $\mathrm{mm} /$ hour) during certain durations (minutes) for various return periods (years) adopted for Batu Kawan

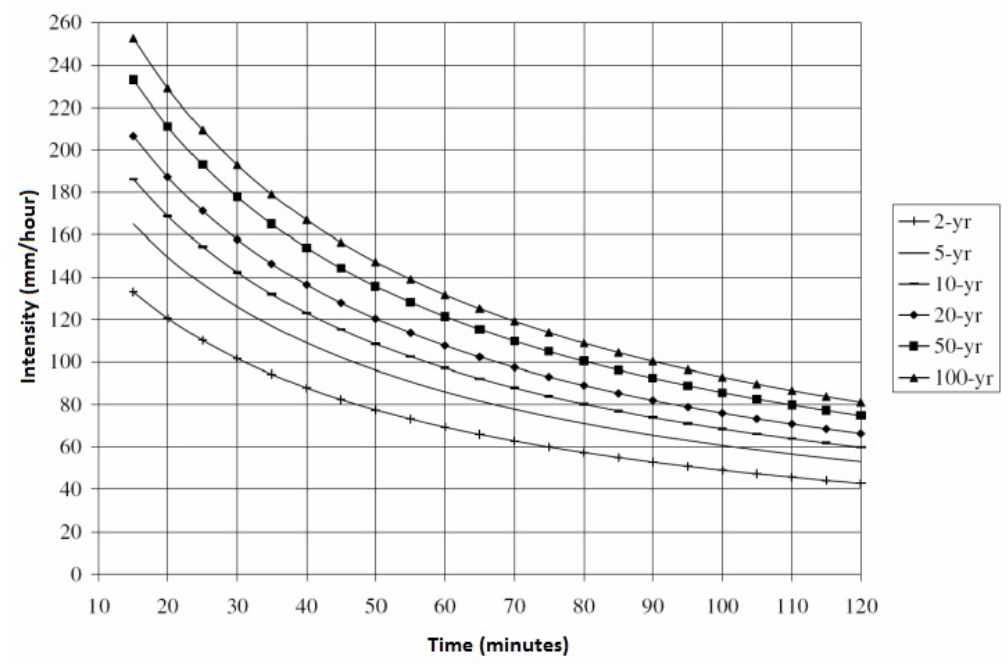

Source: Modified from Jurutera Perunding Consulting Engineers (2008)

Jurutera Perunding Consulting Engineers (2008) give a well-documented overview of the engineering works needed for the management of a 100-year flash flood event. They divide the Batu Kawan site into 24 catchments and model the possible runoff for each of the catchments. The results are used as input for the design of flood channels. Both open and closed channel solutions are suggested depending on the density of the development. The design suggested is based on a scenario where heavy rainfall coincides with mean higher high water (MHHW; average of high tide levels observed during new or full moon) and not with highest astronomical tide (HAT; highest possible tide level without influence of wind, air pressure, temperature, etc., based on 19-year tide tables). However, they recommend that the minimum design platform level for new development should be HAT $+0.5 \mathrm{~m}=2.14 \mathrm{~m}$ land survey datum (LSD) Level to comply with international standards. Further quantifications of MHHW, HAT, and LSD levels are presented in Table 2.

The level of $2.14 \mathrm{~m}$ LSD can be reached by a flood exceeding the five-year design event. A 100-year event would reach approximately $40 \mathrm{~cm}$ above this level. In the sub-catchment C-24, the proposed development level will be $2.60 \mathrm{~m} \mathrm{LSD}$. If this level is adopted in the realisation of the plans, a 100-year flood might cause minor problems in the inner parts of the catchment only (Figure 4).

The temperature in Peninsular Malaysia (meteorological station Petaling Jaya) shows a general increase from 1961 to 2007. A decreasing seasonal rainfall trend for peninsular Malaysia in 1998-2007 can be observed as compared to 1961-1990. The simulated annual temperature up to 2099 shows a significant increase. The simulated annual rainfall shows a decrease for the first 20 years followed by an increase up to 2099 (Malaysian Meteorological Department, 2009). Another study by Manton et al. (2001) on extreme daily rainfall and temperature in the period 1961-1998 shows a general decrease in annual total rainfall in SE Asia, but at the same time a weak increase in extreme rainfall intensity in Peninsular Malaysia. At the east coast of Peninsular Malaysia the nature of 
the flood changes from monsoonal type of flood with long duration, to flash flood with short duration (Mohamad et al., 2012).

Climate change scenarios provided by van Oldenborgh et al. (2013) roughly indicate a possible $10 \%$ increase of precipitation in the area. The changes are larger in the months October to March and less in the months April to September. It should be noted that these scenarios describe mean precipitation for long (six months) periods. They do not capture the increase of short-term high intensity precipitation events. Nonetheless, the possibility of an average increase of $10 \%$ does not require a major adjustment of the drainage design of the site.

Jurutera Perunding Consulting Engineers (2008) mention explicitly the positive effect of natural mangrove vegetation along the coast of the proposed site. This vegetation reduces the effects of flooding. It is therefore suggested that efforts should be done to preserve the still existing mangrove forest and restore those parts that were logged earlier.

We concluded that if the proposed development level of $2.60 \mathrm{~m} \mathrm{LSD}$ is implemented and a well-engineered drainage system adapted to the 100-year flood is constructed and maintained continuously (in particular during flooding), the flooding risk at the construction site is low.

Figure 4 The situation for the flood drainage along a typical longitudinal profile (sub-catchment C-24) (see online version for colours)

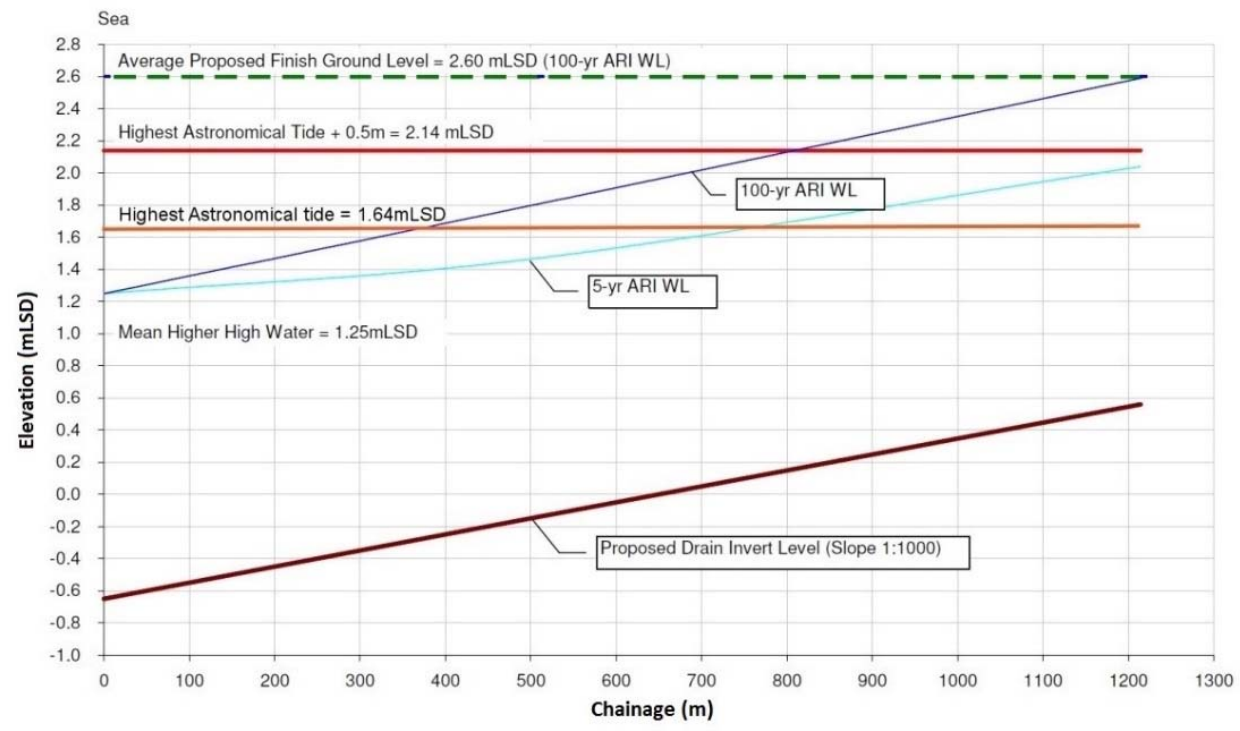

Notes: A flood with a return period of five years will not reach up to the proposed development level (2.60 m LSD) while a 100-year flood event might reach the development level in the inner parts of the catchment

Source: Modified from Jurutera Perunding Consulting Engineers (2008)

\section{Storm surges and sea level rise}

The study site is potentially exposed to coastal flooding. Therefore, storm surge hazards as well as the influence of rising sea levels were investigated. 


\subsection{Storm surges}

Severe storm floods are caused by storm surges triggered in areas with strong tropical or extra-tropical cyclones (von Storch and Woth, 2008). When storm surges hit the coast, they threaten the coastal population and can cause massive destruction of coastal infrastructure and assets (Wolf, 2009). A large number of storm surges have caused severe natural disasters in Asia, e.g., in Bangladesh.

Maximum storm surge water levels depend on intensity, duration, and direction of a surge from cyclone characteristics, local winds, astronomical tides, wave characteristics at the coast, and the bathymetry. The potential impact of storm surges further depends on coastal protection, topography, and land-use. Hence, local conditions have to be analysed. Moreover, storm surge water levels may increase in the long term when sea level is rising. Also anthropogenic factors such as subsidence or urbanisation close to the shore may contribute to the risk of coastal flooding (Nicholls and Cazenave, 2010; Hinkel et al., 2012).

Data about storm surges for this study were limited. Hence, the analysis was restricted to the analysis of tide gauges and the application of the dynamic and interactive vulnerability assessment (DIVA) model and database. Since tropical cyclones have rarely been observed close to the equator (Anthes, 1982; Chang et al., 2003), the site is generally not in the well-known global cyclone tracks. An exception, the typhoon Vamei, which came close enough to the equator to reach also Malaysia was analysed by Chang et al. (2003), who calculated a probability of once in 300-400 years for such an event. A more continuous coastal flood risk may arise from local winds and tidal surge.

The tidal range at the Batu Kawan site is approximately $2 \mathrm{~m}$ (Karim and Ismail, 2010), with mean lower low water (MLLW; average of low tide levels observed during half-moon) at $0.77 \mathrm{~m}$ admiral chart datum (ACD level) and MHHW at 2.67 m ACD (Table 2). For the statistical calculation of a 1:100 year storm surge level, a long-time series of recorded water levels would have been required. Since long-term tide gauge records were not available in this study, the DIVA database (Vafeidis et al., 2008) was employed to derive the 1:100 year storm surge level for the region.

Table 2 Tide levels at Batu Kawan, Dermaga Butterworth, 2008

\begin{tabular}{lcc}
\hline Tide & $\begin{array}{c}\text { Admiral chart datum level } \\
(m \text { ACD })\end{array}$ & $\begin{array}{c}\text { Land survey datum level } \\
(m \text { LSD })\end{array}$ \\
\hline Lowest astronomical tide (LAT) & 0.00 & -1.42 \\
Mean lower low water (MLLW) & 0.77 & -0.65 \\
Mean higher low water (MHLW) & 1.48 & 0.06 \\
Mean sea level (MSL) & 1.72 & 0.30 \\
Mean lower high water (MLHW) & 1.96 & 0.54 \\
Mean higher high water (MHHW) & 2.67 & 1.25 \\
Highest astronomical tide (HAT) & 3.06 & 1.64 \\
\hline
\end{tabular}

Source: Jurutera Perunding Consulting Engineers (2008)

The DIVA database is a global coastal database that underpins the DIVA integrated impact assessment model (McFadden et al., 2007; Hinkel and Klein, 2009). In its present form, the database includes information on more than 80 physical and socio-economic parameters of the coast, including modelled storm surge levels for the 1, 10, 100, and 
1000 years return periods. Extreme water levels in meters above mean sea level (m a.s.l.) are calculated as the sum of

1 a tidal term, i.e., mean high water above mean sea level (MHW, average of all high tide levels observed over a period of 19-years)

2 a barometric term, i.e., sea level rise due to atmospheric depression

3 a wind set-up term.

More detailed information on the calculation of storm surge values is provided by Vafeidis et al. (2006). The results show that the one-year storm-surge level of $1.93 \mathrm{~m}$ a.s.l. (3.65 m ACD) derived from DIVA (Table 3) agrees well with the mean annual maximum water level observation of $3.65 \mathrm{~m} \mathrm{ACD}$ for the years 1984-1987 and 1990-1995 at the tide gauge in Lutum (http://www.gloss-sealevel.org/ station_handbook/stations/43/), located approximately $150 \mathrm{~km}$ south of the study site.

The 100-year storm surge water level modelled with DIVA for the Penang coastline segment is $2.29 \mathrm{~m}$ a.s.l. ( $2.59 \mathrm{~m} \mathrm{LSD}$ ). This value corresponds to the proposed development level at the site of $2.60 \mathrm{~m} \mathrm{LSD}$. However, it has to be taken into account that sea level may rise in the future and/or that simultaneously occurring events, e.g., rainfall, may increase local water levels additionally.

Table 3 Modelled storm surge water levels from DIVA

\begin{tabular}{lccc}
\hline Return period & $\begin{array}{c}\text { Values derived from } \\
\text { DIVA }(m \text { a.s.l. })\end{array}$ & $\begin{array}{c}\text { Admiral chart datum } \\
\text { level }(m \text { ACD })\end{array}$ & $\begin{array}{c}\text { Land survey datum } \\
\text { level }(m \text { LSD })\end{array}$ \\
\hline $1: 1$ & $1.93 \mathrm{~m}$ & $3.65 \mathrm{~m}$ & $2.23 \mathrm{~m}$ \\
$1: 100$ & $2.29 \mathrm{~m}$ & $4.01 \mathrm{~m}$ & $2.59 \mathrm{~m}$ \\
\hline
\end{tabular}

\subsection{Sea level rise due to climate change}

Global sea levels have been rising throughout the 20th and 21st centuries and are expected to continue to rise for centuries as a consequence of climate change, even under the most optimistic mitigation scenarios (Nicholls et al., 2007). The global mean rate was $1.7 \mathrm{~mm} /$ year between 1901 and 2010, with a higher rate of $3.2 \mathrm{~mm} /$ year observed between 1993 and 2010 (Church et al., 2013a). While acceleration of SLR is expected to continue, significant uncertainties exist regarding the final magnitude of the rise primarily due to the potential contribution of the Greenland and West Antarctic ice sheets (Bittermann et al., 2013; Church et al., 2013b) and regional sea-level variations (Nicholls and Cazenave, 2010). In its Fourth Assessment Report (AR4), the Intergovernmental Panel on Climate Change (Bindoff et al., 2007) projects a mean global SLR of up to 0.59 $\mathrm{m}$ by the end of the 21 st century, not taking into account possible contributions from the melting of the large ice sheets. These contributions have been considered in the Fifth Assessment Report (AR5; Church et al., 2013a) and projections have been revised upwards. Moreover, studies based on semi-empirical methods that also take into account such contributions suggest that sea levels may rise beyond $1.5 \mathrm{~m}$ by 2100 compared to 1990 levels (Vermeer and Rahmstorf, 2009; Rahmstorf, 2010). However, it must be noted that these values refer to a theoretical global mean. Sea levels vary spatially around the globe as regional sea levels are affected by changes in oceanic or atmospheric circulation 
(Milne et al., 2009). These changes occur on decadal time scales and can be of significant magnitude, which can considerably exceed or counteract global SLR.

For the purposes of this study, we used the DIVA integrated assessment model to calculate relative SLR rates for the region of interest until the year 2100. SLR estimates in DIVA are computed with the intermediate complexity climate model CLIMBER-2 (Petoukhov et al., 2000) using the Special Report on Emissions Scenarios (SRES). The calculation of relative SLR also includes natural subsidence/uplift rates due to isostatic adjustment based on the geophysical model of Peltier (2000) and an assumed uniform subsidence of $2 \mathrm{~mm} /$ year in delta areas (Vafeidis et al., 2006).

Three SRES scenarios (A2, B1, A1B) and two SLR scenarios (high regionalised and low regionalised) were employed to produce a wide range of possible rises in sea levels for the region. High and low SLR scenarios represent the variability in the response of sea levels to climate sensitivity within each SRES scenario. Regionalised patterns of sea levels are based on a regionalisation of the thermal expansion component. The results vary between 7 and $32 \mathrm{~cm}$ in 2050 and 12 and $87 \mathrm{~cm}$ in 2100, with average values of 19 and $49 \mathrm{~cm}$, respectively (Figure 5).

Figure 5 Calculated future relative sea-level rise (RSLR) in the study region for three SRES (A2, B1, A1B) and two SLR scenarios (high regionalised and low regionalised) representing the variability in the response of sea levels to climate sensitivity within each SRES scenario (see online version for colours)

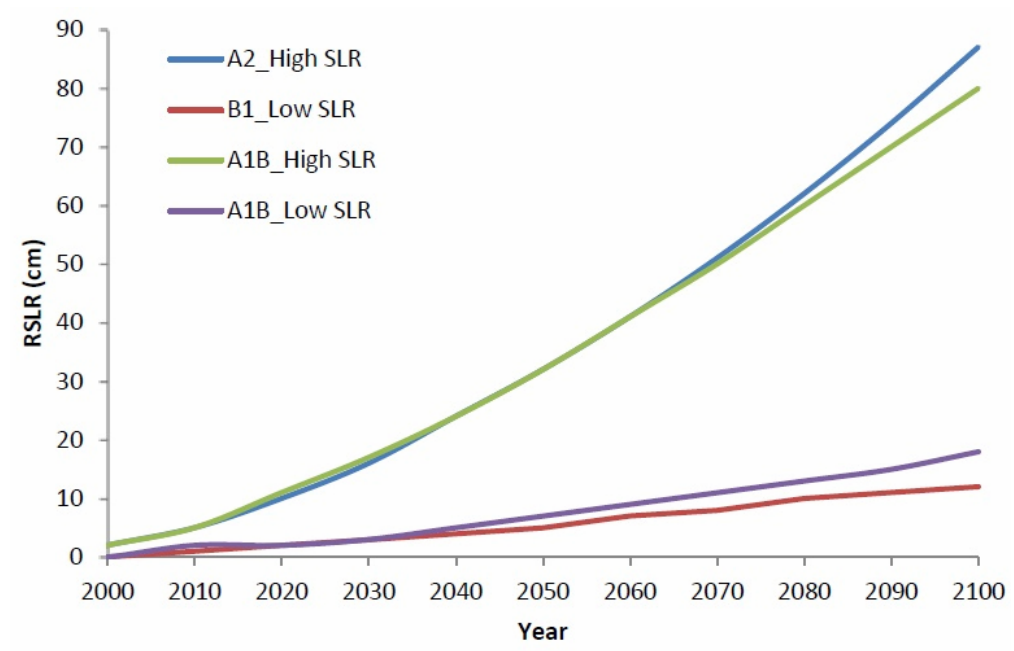

There is a limited amount of data assessing SLR rates or forecasting future SLR in the region. The only information on estimated SLR rates for four tide gauge stations was included in a report published by Mohazri and Hazari (2010). Reported rates are of the order of $1 \mathrm{~mm} /$ year and are comparable to the low-range estimates from the DIVA model. Similarly, some additional information was included in a study based on combinations of satellite observations of Indian Ocean sea levels, in-situ measurements, and climate model simulations (Han et al., 2010). Although the study reported large variations for the Indian Ocean, estimates for the region of interest did not exceed $20 \mathrm{~cm}$ for 2100 and were also within the range of the lower estimates produced with the DIVA model (B1_Low SLR and A1B_Low SLR). 
Based on the above model runs and available data, we assessed with high confidence SLR will not exceed $55 \mathrm{~cm}$ and is likely to remain below $30 \mathrm{~cm}$ through 2100 .

\section{Tsunamis}

\subsection{Historical perspective}

Available tsunami data from the two largest online catalogues available (National Geophysical Data Centre, NGDC http://www.ngdc.noaa.gov/hazard/tsu.shtml; Tsunami Laboratory Novosibirsk, TLN http://tsun.sscc.ru/) were merged by Løvholt et al. (2012a). Historical tsunamis in the region are limited in numbers. Most of them are of seismic origin, but some of the events closest to the site of interest may have been caused by landslides. Further, most of the historical events are local affecting Sumatra and coastlines close to Banda Aceh only. However, distant sources could pose a threat to the proposed site.

The observed run-up heights of the 2004 Indian Ocean tsunami at Penang Island varied from $2.3 \mathrm{~m}$ to $4.0 \mathrm{~m}$ (Yalciner et al., 2005; Synolakis and Kong, 2006; Koh et al., 2009). Along an approximately $130 \mathrm{~km}$ long segment of the mainland Kedah, Penang, and Perak state coastlines northwards from Kuala Kurau (about $30 \mathrm{~km}$ south of Batu Kuwan), the observed run-up heights varied from $0.90 \mathrm{~m}$ to $3.80 \mathrm{~m}$ (Koh et al., 2009).

Volcano tsunamis in Southeast Asia area reviewed by Paris et al. (2014). The 27 August 1883 Krakatau volcano in the Sunda Strait between Sumatra and Java, Indonesia, generated a tsunami that devastated the adjacent coastlines of Java and Sumatra with a maximum run-up height of $42 \mathrm{~m}$. At least 36,000 people were killed (mostly by the tsunami), see, e.g., Verbeek (1885), Symons (1888), Murty (1977), Simkin and Fiske (1983), Bryant (2001), Choi et al. (2003), and Pelinovsky et al. (2005). The authors of the present paper have not been able to find any description from which it seems possible to deduce wave heights in Peninsular Malaysia or the Malacca Strait; but from the literature cited above, these wave heights must have been rather limited. This limiting effect is mainly caused by the favourable location of the Malacca Strait and because tsunamis generated by a volcano (or landslide) decay faster in the far-field than tsunamis generated by an earthquake.

\subsection{Tsunamigenic earthquake sources}

The lower bound return period for megathrust events like the one on 26th December 2004 is $300-400$ years. The largest credible earthquake to be prepared for within the next 50-100 years, where the resulting tsunami could hit the coast of Thailand and the Peninsular Malaysia, is a $\mathrm{M}_{\mathrm{w}} 8.5$ event along the Sunda Arc subduction zone with an estimated lower bound return period of 200 years (Løvholt et al., 2006; NGI, 2006). Seismic tsunamigenic events along the fracture zone in the Andaman Sea and along the northwestwardly extension of the Great Sumatra fault are less likely than repeated dip-slip movements in the Sunda Arc subduction zone itself (NGI, 2006). Simulations of a $\mathrm{M}_{\mathrm{w}} 8.9$ scenario located in the northern part of Bengal Bay (along the Burma fault, with a return period of roughly 500 years) show that the tsunami threat for Batu Kawan is smaller for this scenario than for a $M_{w} 8.5$ Sunda Arc scenario (NGI, 2009a; Løvholt et al., 2012b). 
A further analysis of the simulations of the $\mathrm{M}_{\mathrm{w}} 9.32004$ Sumatra earthquake tsunami (Glimsdal et al., 2006; Løvholt et al., 2006; NGI, 2006) gives a maximum shoreline water level of about $3.5^{\circ} \mathrm{m}$ west of Penang and about $2 \mathrm{~m}$ for the Batu Kawan site.

From the considerations above, it was assessed that the largest credible earthquake to be prepared for within the next 50-100 years, where the generated tsunami could hit the coast of Peninsular Malaysia, was a $\mathrm{M}_{\mathrm{w}} 8.5$ event along the Sunda Arc subduction zone. The estimated lower bound return period of such an earthquake is of the order of 200 years (this period can perhaps be much longer; NGI, 2014b). Because of the substantial stress release during the mega-earthquake of 26 December 2004, the annual occurrence probability of such a mega-earthquake on a critical section of the Sunda Arc is assessed to be less than $0.1 \%$ during the 21 st century.

\subsection{Tsunamigenic landslide and volcano sources}

For the landslide to be tsunamigenic, a large volume in combination with a rapid flow is generally required, making such tsunamis infrequent. An exception is the occurrence of local landslides with more limited volumes that generate tsunamis in the presence of steep relief's combined with weak soil materials. Examples such as the 1992 Flores Island (Yeh et al.,, 1993) and the 1899 Ceram (Berninghausen, 1969; Soloviev and Go, 1974) events in eastern Indonesia demonstrate the latter. Such landslides are often triggered by an earthquake. Two of the historical tsunami events closest to the site of interest may have been caused by landslides due to their local character. They originate from the Banda Aceh area (in 1964 and 1967, see Soloviev and Go, 1974; NGI, 2011a; Løvholt et al., 2012a).

Being often less probable and generally less geologically constrained than large earthquakes, possible tsunamigenic landslide sources are harder to identify. This lack of data increases the uncertainty of the hazard evaluation. In the absence of more accurate (and considerably more expensive) detailed geophysical seabed surveys, only available data were applied. Lin et al. (2010) identified three sediment packages that exhibit sliding characteristics in the Malacca Strait-Mergui Basin shelf margin NE of northernmost Sumatra. Dating of these landslides to 20-30, 342-364, and 435-480 kyr BP, shows that they all occurred near times of sea-level low-stands, which could indicate that a large amount of direct sediment influx during glacial periods was an essential precondition for basin-margin landsliding. Lin et al. (2010) conclude that the chance of having a repeat submarine landslide and tsunami along the Malacca Strait-Mergui Basin margin during the current Holocene sea-level high-stand is low. The basis for this conclusion is the lack of rapid deposition on the continental slope, in spite of high sediment flux and tectonic subsidence rate that normally weaken the slope stability. Landslide tsunami hazard is discussed further by Harbitz et al. (2014)

Schwab et al. (2012) showed evidence for submarine landslides on the western slope offshore Thailand. Time intervals between individual events are long (hundred ka to Ma). Based on volume and water depth criteria, they conclude that only a few slope failures may have been tsunamigenic, indicating a low tsunami hazard. However, the criteria are disputable, see, e.g., Lo Iacono et al. (2012) on deep-water slope failure tsunamis.

Based on the historical and geological records, the likelihood of landslide tsunamis affecting the Batu Kuwan site was considered relatively small. However, landslide tsunamis have previously been underreported and the incompleteness of the historical 
catalogue introduces large uncertainties. As a consequence, the historical catalogue may underestimate the hazard.

The likelihood of volcano tsunamis affecting the Batu Kuwan site was also found to be small. There are no historic reports of volcano tsunamis reaching Peninsular Malaysia. Further, Paris et al. (2014) report that the sources of past volcano tsunami events in Southeast Asia are all located further east. Except from the 1888 Ritter Island and the 1883 Krakatau tsunamis, all victims of the past events were less than $20 \mathrm{~km}$ from the source.

\subsection{Largest credible tsunami scenarios}

Based on the evaluations and findings above, the impact of two $M_{w} 8.5$ earthquake tsunami scenarios located along the Sunda Arc subduction zone on the Batu Kawan site (estimated lower bound return period of the order of 200 years; Figure 6) was calculated. The scenarios are located in areas that are tectonically justifiable and at the same time where the effects in the Malacca Strait would be the worst.

For propagation, the GloBouss model (Pedersen and Løvholt, 2008) was applied in a linear hydrostatic mode. For the near shore propagation and inundation, the ComMIT model (Løvholt et al., 2010; ComMIT, 2011) was applied, taking nonlinearities in the shallow water propagation (including potential wave breaking) around Batu Kawan into account. For the propagation, 30 arc sec $(\sim 900 \mathrm{~m})$ bathymetric and topographic data from GEBCO (2011) were employed (resampled into a coarser grid of 1 arc min or $\sim 1.8 \mathrm{~km}$ in the simulations). For the near shore and inundation modelling, the GEBCO bathymetry was combined with the $90 \mathrm{~m}$ resolution SRTM data (http://www2.jpl.nasa.gov/srtm) on the landside.

Figure 6 Maximum tsunami surface elevations ( $m$ a.s.l.) during generation and propagation for, (a) the northern (b) the southern $\mathrm{M}_{\mathrm{w}} 8.5$ earthquake sources (see online version for colours)

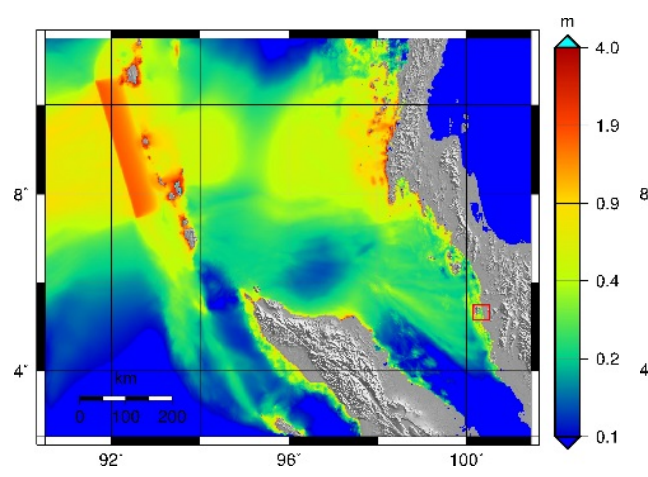

(a)

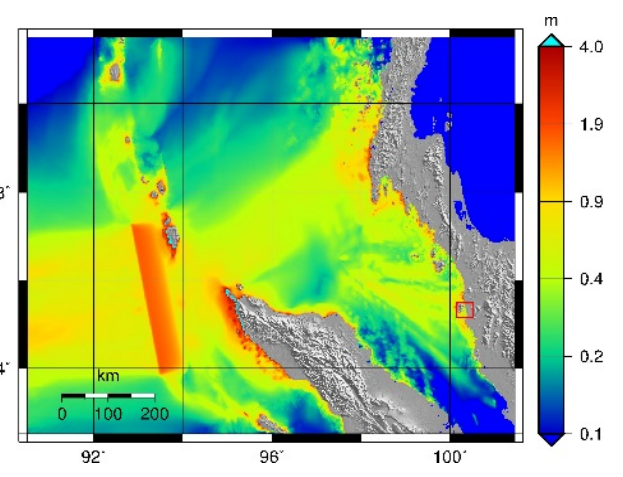

(b)

Notes: The source locations are revealed as a salient high-surface-elevation area in each of the two panels. The Batu Kawan site is indicated by a red rectangle.

The maximum surface elevations during the offshore propagation are given in Figure 6. The maximum surface elevation is reduced from approximately $2 \mathrm{~m}$ a.s.l. in the source area down to about $20 \mathrm{~cm}$ a.s.l. (northern source) and $40 \mathrm{~cm}$ a.s.l. (southern source) close to the site. At Batu Kawan, the maximum inundation heights are about 20 
$\mathrm{cm}$ a.s.1. and $40 \mathrm{~cm}$ a.s.l. for the northern and southern sources, respectively (Figure 7). Since the applied SRTM topography data set is coarse and also influenced by vegetation offset (implying too high elevation of the site area), the calculated inundation heights will generally be underestimated in places with a gentle coastal terrain. To compensate for these effects, the inundation heights were doubled to give an upper limit of 0.5-1 m a.s.l. at the site.

Figure 7 Maximum offshore surface elevation and maximum on land inundation height for the tsunami impacting the Batu Kawan site (at $5^{\circ} 13^{\prime}$ n) for, (a) the northern (b) southern $\mathrm{M}_{\mathrm{w}} 8.5$ earthquake sources ( $\mathrm{m}$ a.s.1.) (see online version for colours)

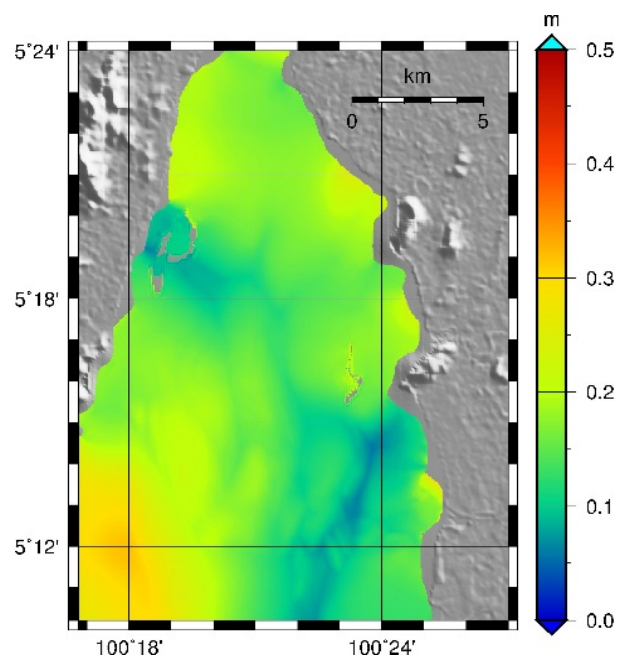

(a)

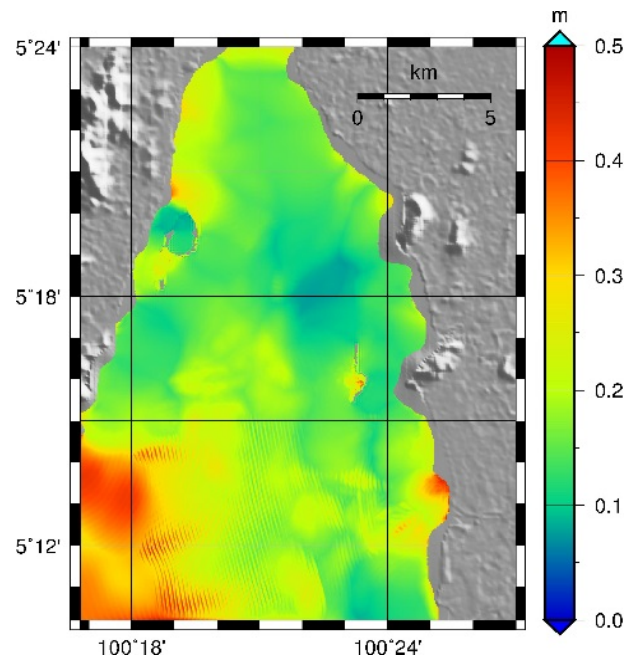

(b)

\section{Natural hazards not related to flooding}

\subsection{Earthquake hazard}

The seismic potential of the Sumatran subduction zone is considered high in the region from $2^{\circ} \mathrm{N}$ to $5^{\circ} \mathrm{S}$. A large event with $\mathrm{M}_{\mathrm{w}}$ greater than 7.8 may generate destructive ground motions in Singapore and Kuala Lumpur, even at a distance of $700 \mathrm{~km}$ (Megawati et al., 2005). ${ }^{1}$ The hazard related to direct seismic loading in Peninsular Malaysia was briefly evaluated and found to be low (for relative hazard classified into four categories on the basis of MMI intensity: negligible, low, moderate, and high; NGI, 2009b). However, this hazard might still be relevant for installations sensitive to seismic loading.

\subsection{Volcano hazard}

There are no volcanoes in Peninsular Malaysia. However, parts of Peninsular Malaysia might be impacted by ashfall from volcanic eruptions in Indonesia (NGI, 2011b). The hazard level related to volcanoes was found to be negligible. The knowledge on volcano ashfall hazard is currently being advanced, see, e.g., the Global Volcano Model (http://globalvolcanomodel.org/hazard-modelling/tephra-hazard-modelling/). 


\section{Multi hazard analysis and concluding remarks}

This study provided a unified screening of multiple natural hazards that might affect the Batu Kawan manufacturing site in Malaysia. More detailed studies of the individual hazard components were not given preference for the immediate practical applications.

The hazard components were considered for various return periods. However, based on common practice and the already proposed development level of the site, a 100-200 year design return period was selected for comparisons in the multi-hazard analysis. This study considered combined effects of tides and storm surges, as well as the cascading effects of earthquakes and tsunamis. Independent extreme events were considered separately. Where relevant data were available, the hazards were assessed quantitatively. Otherwise, they were assessed relatively.

Table 4 summarises the results. There is significant uncertainty associated with the recommended design values (and in some cases return periods). Storm surge water levels might increase further in combination with heavy rainfall and flash floods. However, a further analysis of the possible inundation levels requires more detailed information on the topography (digital elevation model with higher vertical and horizontal resolution) and longer time series of the relevant tide gauges.

Table 4 Exposure of the Batu Kawan site to natural hazards

\begin{tabular}{|c|c|c|}
\hline $\begin{array}{l}\text { Type of } \\
\text { hazard }\end{array}$ & $\begin{array}{l}\text { Level of hazard/ } \\
\text { recommended } \\
\text { design value }\end{array}$ & Comments \\
\hline Flood & 2.6 m LSD* & $\begin{array}{l}\text { Proper drainage should be designed to handle this level of } \\
\text { flood water. The level of } 2.6 \mathrm{~m} \text { LSD is only likely to occur } \\
\text { in the inner parts of the drainage system. }\end{array}$ \\
\hline $\begin{array}{l}\text { Tropical } \\
\text { cyclone }\end{array}$ & Low & The site is not in the typical path of tropical cyclones. \\
\hline $\begin{array}{l}\text { Tide and } \\
\text { storm surge }\end{array}$ & 2.6 m LSD* & 100-year event. \\
\hline Sea level rise & $<0.5 \mathrm{~m}$ & $\begin{array}{l}\text { Sea level rise over the next } 100 \text { years can be assumed to be } \\
\text { less than } 0.55 \mathrm{~m} \text { and is likely to be less than } 0.30 \mathrm{~m} \text {. }\end{array}$ \\
\hline Tsunami & $\begin{array}{l}0.8-1.3 \mathrm{~m} \mathrm{LSD} \\
\text { inundation height }\end{array}$ & $\begin{array}{c}\text { Tsunami inundation heights estimated for } \mathrm{M}_{\mathrm{w}} 8.5 \\
\text { earthquake scenarios located along the Sunda Arc; } \\
\text { estimated lower bound return period of the order of } 200 \\
\text { years (considered the largest credible earthquake to be } \\
\text { prepared for within the next } 50-100 \text { years). Uncertainty } \\
\text { about the tsunamigenic potential in the Andaman fracture } \\
\text { zone. }\end{array}$ \\
\hline Earthquake & Low & $\begin{array}{l}\text { If the foreseen installations are sensitive to seismic } \\
\text { loading, a site-specific seismic hazard evaluation is } \\
\text { recommended. }\end{array}$ \\
\hline Volcano & Negligible & $\begin{array}{c}\text { The site might be affected by ashfall from a major volcanic } \\
\text { eruption in Sumatra. }\end{array}$ \\
\hline
\end{tabular}

Note: * Land survey data level, proprietary Malaysian standard; $30 \mathrm{~cm}$ above mean sea level.

Once the critical phenomena are identified by a preliminary analysis like this one, a detailed analysis of hazard (e.g., frequency and intensity of event), risk (including 
potential consequences), and risk mitigation measures (including also installation of possible sensitive equipment) should be carried out for meaningful comparisons and risk assessments. However, models for coastal inundation (tsunami) vulnerability and risk analysis are currently at a premature state (Nadim and Glade, 2006; Løvholt et al., 2012b; González-Riancho et al., 2014; Løvholt et al., 2014). Moreover, a further discussion of possible damages at the site is not feasible without high quality topography data, information on buildings and infrastructure to be implemented (location, design, and use), as well as the expected number and location of people to be present at various times. Such information will only be available in the later stages of plant projects like this case study.

Based on this preliminary multi-hazard analysis, the Bosch Solar Energy AG decided to elevate the manufacturing site by $0.5 \mathrm{~m}$ : Whereas the proposed development level and drainage system were designed to cope with floods up to $2.6 \mathrm{~m}$, Bosch - following a precautionary principle - also wanted to protect the site from floods in combination with an additional sea level rise in the long run.

This study illustrates the utility of (preliminary) hazard analyses, in particular in view of the insignificant costs compared to the total investment costs for the site or the possible costs of an undesired event. Such preliminary analyses further aid to identify the main sources of uncertainties and thus the most favourable issues for follow-up studies.

\section{Acknowledgements}

Three anonymous reviewers are thanked for valuable comments that clearly helped to improve the manuscript. R. Gilbert is thanked for a linguistic revision. The work on this manuscript has been financially supported by NGI Oslo, International Centre for Geohazards (ICG), and the Research Council of Norway.

\section{References}

Anthes, R.A. (1982) Tropical Cyclones: Their Evolution, Structure and Effects, 208pp, Amer. Meteor. Soc., Boston.

Bell, R. and Glade, T. (2004) 'Multi-hazard analysis in natural risk assessments', in Brebbia, C.A. (Ed): International Conference on Computer Simulation in Risk Analysis and Hazard Mitigation, 26-29 September, pp.197-206, WIT Press, Rhodes, GR.

Berninghausen, W.H. (1969) 'Tsunamis and seismic seiches of Southeast Asia', Bulletin of the Seismological Society of America, Vol. 59, No. 1, pp.289-297.

Bindoff, N.L., Willebrand, J., Artale, V., Cazenave, A., Gregory, J., Gulev, S., Hanawa, K., Le Quéré, C., Levitus, S., Nojiri, Y., Shum, C.K., Talley, L.D. and Unnikrishnan, A. (2007) 'Observations: oceanic climate change and sea level', in Solomon, S., Qin, D., Manning, M., Chen, Z., Marquis, M., Averyt, K.B., Tignor, M. and Miller, H.L. (Eds.): Climate Change 2007: The Physical Science Basis. Contribution of Working Group I to the Fourth Assessment Report of the Intergovernmental Panel on Climate Change, Cambridge University Press, Cambridge, UK and New York, NY, USA.

Bittermann, K., Rahmstorf, S., Perrette, M. and Vermeer, M. (2013) 'Predictability of twentieth century sea-level rise from past data', Environmental Research Letters, Vol. 8, No. 1, p.014013.

Bryant, E. (2001) Tsunami: The Underrated Hazard, Cambridge University Press, Cambridge. 
Chang, C.P., Liu, C.H. and Kuo, H.C. (2003) 'Typhoon Vamei: an equatorial tropical cyclone formation', Geophysical Research Letters, Vol. 30, p.1150, 4pp, doi:10.1029/2002GL016365.

Choi, B.H., Pelinovsky, E., Kim, K.O. and Lee, J.S. (2003) 'Simulation of the trans-oceanic tsunami propagation due to the 1883 Krakatau volcanic eruption', Nat. Hazards Earth Syst. Sci., Vol. 3, No. 5, pp.321-332, doi:10.5194/nhess-3-321-2003.

Christensen, C.M., King, S., Verlinden, M. and Yang, W. (2008) 'The new economics of semiconductor manufacturing', IEEE Spectrum, Vol. 5 [online] $\mathrm{http} / /$ spectrum.ieee.org/semiconductors/design/the-new-economics-of-semiconductormanufacturing (accessed 1 March 2015).

Church, J.A., Clark, P.U., Cazenave, A., Gregory, J.M., Jevrejeva, S., Levermann, A., Merrifield, M.A., Milne, G.A., Nerem, R.S., Nunn, P.D., Payne, A.J., Pfeffer, W.T., Stammer, D. and Unnikrishnan, A.S. (2013a) 'Sea level change', in Stocker, T.F., Qin, D., Plattner, G-K., Tignor, M., Allen, S.K., Boschung, J., Nauels, A., Xia, Y., Bex, V. and Midgley, P.M. (Eds.): Climate Change 2013: The Physical Science Basis. Contribution of Working Group I to the Fifth Assessment Report of the Intergovernmental Panel on Climate Change, Cambridge University Press, Cambridge, UK and New York, NY, USA.

Church, J.A., Monselesan, D., Gregory, J.M. and Marzeion, B. (2013b) 'Evaluating the ability of process based models to project sea-level change', Environmental Research Letters, Vol. 8, No. 1, p.014051.

ComMIT (2011) Community Model Interface for Tsunami [online] http://nctr.pmel.noaa.gov/ComMIT/ (accessed 2 July 2015).

European Commission (2010) Risk Assessment and Mapping Guidelines for Disaster Management, Commission staff Working paper, December, Brussels.

Garcia-Aristizabal, A., Marzocchi, W., Woo, G., Reveillere, A., Douglas, J., Le Cozannet, G., Rego, F., Colaco, C., Fleming, K., Pittore, M., Tyagunov, S., Vorogushyn, S., Nadim, F., Vangelsten, B.V. and ter Horst, W. (2012) Review of Existing Procedures for Multi-Hazard Assessment, Deliverable 3.1 - New methodologies for multi-hazard and multi-risk assessment methods for Europe (MATRIX project), European Commission FP7 Contract No. 265138.

Garcin, M., Desprats, J., Fontaine, M., Pedreros, R., Attanayake, N., Fernando, S., Siriwardana, C., de Silva, U. and Poisson, B. (2008) 'Integrated approach for coastal hazards and risks in Sri Lanka', Nat. Hazards Earth Syst. Sci., Vol. 8, No. 3, pp.577-586, doi:10.5194/nhess-8-5772008.

GEBCO (2011) The General Bathymetric Chart of the Oceans [online] $\mathrm{http}: / /$ www.gebco.net/data_and_products/gridded_bathymetry_data/(accessed 2 July 2015).

Glimsdal, S., Pedersen, G., Atakan, K., Harbitz, C.B., Langtangen, H.P. and Løvholt, F. (2006) 'Propagation of the Dec. 26, 2004 Indian Ocean Tsunami: effects of dispersion and source characteristics', International Journal of Fluid Mechanic Research, Vol. 33, No. 1, pp.15-43, doi:10.1615/InterJFluidMechRes.v33.i1.30.

González-Riancho, P., Aliaga, B., Hettiarachchi, S., González, M. and Medina, R. (2014) 'A contribution to the selection of tsunami human vulnerability indicators: conclusions from tsunami impacts in Sri Lanka and Thailand (2004), Samoa (2009), Chile (2010) and Japan (2011)', Nat. Hazards Earth Syst. Sci. Discuss., Vol. 2, No. 2, pp.7679-7734, doi:10.5194/nhessd-2-7679-2014.

Government of Malaysia Department of Irrigation and Drainage Malaysia (2009) Volume 1 - Flood Management.

Government of Malaysia Department of Irrigation and Drainage Malaysia (2011) List Over Relevant Flash Floods in Malaysia [online] http://www.water.gov.my (accessed February 2011).

Grünthal, G., Thieken, A., Schwarz, J., Radtke, K., Smolka, A. and Merz, B. (2006) 'Comparative risk assessment for the city of Cologne - storms, floods, earthquakes', Nat Hazards, Vol. 38, Nos. 1-2, pp.21-44. 
GSA - US General Services Administration (2015) Site Selection Guide [online] http://www.gsa.gov/graphics/pbs/ GSA_Site_Selection_Guide_R2-sY2-i_0Z5RDZ-i34K-pR.pdf (accessed 1 March 2015).

Han, W., Meehl, G.A., Rajagopalan, B., Fasullo, J.T., Hu, A., Lin, J., Large, W.G., Wang, J-W., Quan, X-W., Trenary, L.L., Wallcraft, A., Shinoda, T. and Yeage, S. (2010) 'Patterns of Indian Ocean sea-level change in a warming climate', Nature Geoscience, Vol. 3, No. 8, pp.546-550, doi:10.1038/ngeo901.

Harbitz, C.B., Løvholt, F. and Bungum, H. (2014) 'Submarine landslide tsunamis - how extreme and how likely?', Natural Hazards, Vol. 72, No. 3, pp.1341-1374, doi: 10.1007/ s11069-013-0681-3.

Hinkel, J. and Klein, R.J.T. (2009) 'Integrating knowledge to assess coastal vulnerability to sea-level rise: the development of the DIVA tool', Global Environmental Change-Human and Policy Dimensions, Vol. 19, No. 3, pp.384-395.

Hinkel, J., Brown, S., Exner, L., Nicholls, R.J., Vafeidis, A.T. and Kebede, A.S. (2012) 'Sea-level rise impacts on Africa and the effects of mitigation and adaptation: an application of DIVA', Regional Environmental Change, Vol. 12, No. 1, pp.207-224.

Jurutera Perunding Consulting Engineers (2008) Batu Kawan Drainage and Storm Water Master Plan Study, Final Report, August.

Kappes, M.S., Keiler, M., Elverfeldt, K. and Glade, T. (2012) 'Challenges of analysing multi-hazard risk: a review', Nat Hazards, Vol. 64, No. 2, pp.1925-1958, doi:10.1007/s11069012-0294-2.

Karim, M.F. and Ismail, A.I. (2010) 'Estimation of expected maximum water level due to tide and tsunami interaction along the coastal belts of Penang Island in peninsular Malaysia', Journal of Tsunami Society International, Vol. 29, No. 3, pp.127-138.

Koh, H.L., Teh, S.Y., Liu, P.L-F., Ismail, A.I.M. and Lee, H.L. (2009) 'Simulation of Andaman 2004 tsunami for assessing impact on Malaysia', Journal of Asian Earth Sciences, Vol. 36, No. 1, pp.74-83, doi:10.1016/j.jseaes.2008.09.008.

Lin, Y.N., Sieh, K. and Stock, K. (2010) 'Submarine landslides along the Malacca Strait-Mergui Basin shelf margin: insights from sequence-stratigraphic analysis', Journal of Geophysical Research, Vol. 115, No. B12102, doi:10.1029/2009JB007050.

Lo Iacono, C., Gràcia, E., Zaniboni, F., Pagnoni, G., Tinti, S., Bartolomé, R., Masson, D.G., Wynn, R.B., Lourenço, N., de Abreu, M.P., Dañobeitia, J.J. and Zitellini, N. (2012) 'Large, deepwater slope failures: implications for landslide-generated tsunamis', Geology, Vol. 40, No. 10, pp.931-934, doi:10.1130/G33446.1.

Løvholt, F., Bungum, H., Harbitz, C.B., Glimsdal, S., Lindholm, C.D. and Pedersen, G. (2006) 'Earthquake related tsunami hazard along the western coast of Thailand', Nat. Hazards Earth Syst. Sci., Vol. 6, No. 6, pp.979-997, doi:10.5194/nhess-6-979-2006.

Løvholt, F., Glimsdal, S., Harbitz, C.B., Zamora, N., Nadim, F., Peduzzi, P., Dao, H.I. and Smebye, H. (2012b) 'Tsunami hazard and exposure on the global scale', Earth-Science Reviews, Vol. 110, Nos. 1-4, pp.58-73, doi:10.1016/j.earscirev.2011.10.002.

Løvholt, F., Kühn, D., Bungum, H., Harbitz, C.B. and Glimsdal, S. (2012a) 'Historical tsunamis and present tsunami hazard in eastern Indonesia and the southern Philippines', Journal of Geophysical Research, Vol. 117, No. B9, p.B09310, 19pp, doi: 10.1029/2012JB009425.

Løvholt, F., Pedersen, G. and Glimsdal, S. (2010) 'Coupling of dispersive tsunami propagation and shallow water coastal response', in Zahibo, N., Pelinovsky, E., Yalciner, A. and Titov, V. (Eds.): Proceedings of the 'Caribbean Waves 2008' Workshop in Guadeloupe Dec. 2008: The Open Oceanography Journal, Special Volume.

Løvholt, F., Setiadi, N.J., Birkmann, J., Harbitz, C.B., Bach, C., Fernando, N., Kaiser, G. and Nadim, F. (2014) 'Tsunami risk reduction - are we better prepared today than in 2004?', International Journal of Disaster Risk Reduction, Vol. 10, Part A, pp.127-142, doi:10.1016/j.ijdrr.2014.07.008. 
Malaysian Meteorological Department (2009) Climate Change Scenarios for Malaysia 2001-2099, Scientific Report, ISBN 978-083-99679-1-3.

Manton, M.J., Della-Marta, P.M., Haylock, M.R., Hennessy, K.J., Nicholls, N., Chambers, L.E., Collins, D.A., Daw, G., Finet, A., Gunawan, D., Inape, K., Isobe, H., Kestin, T.S., Lefale, P., Leyu, C.H., Lwin, T., Maitrepierre, L., Ouprasitwong, N., Page, C.M., Pahalad, J., Plummer, N., Salinger, M.J., Suppiah, R., Tran, V.L., Trewin, B., Tibig, I. and Yee, D. (2001) 'Trends in extreme daily rainfall and temperature in Southeast Asia and the South Pacific: 1961-1998', Int. J. Climatol., Vol. 21, No. 3, pp.269-284, doi: 10.1002:joc.610.

McFadden, L., Nicholls, R.J., Vafeidis, A.T. and Tol, R.S.J. (2007) 'A methodology for modelling coastal space for global assessment', Journal of Coastal Research, Vol. 23, No. 4, pp.911-920, doi:10.2112/04-0365.1.

Megawati, K., Pan, T-C. and Koketsu, K. (2005) 'Response spectral attenuation relationships for Sumatran-subduction earthquakes and the seismic hazard implications to Singapore and Kuala Lumpur', Soil Dynamics and Earthquake Engineering, Vol. 25, No. 1, pp.11-25, doi:10.1016/j.soildyn.2004.08.003.

Milne, G.A., Gehrels, W.R., Hughes, C.W. and Tamisiea, M.E. (2009) 'Identifying the causes of sea-level change', Nature Geoscience, Vol. 2, No. 7, pp.471-478, doi:10.1038/ngeo544.

Mohamad, S., Hashim, N.M., Aiyub, K. and Toriman, M.E. (2012) 'Flash flood and community's response at Sg. Lembing, Pahang', Advances in Natural and Applied Sciences, Vol. 6, No. 1, pp.19-No. 25, ISSN 1995-0772.

Mohazri, S. and Hazari, S. (2010) 'Impacts of climate change on the straits of Malacca: the 'three major effects' and their policy remedies', Presented at the 2010 International Climate Change Adaptation Conference: Climate Adaptation Futures - Preparing for the Unavoidable Impacts of Climate Change [online] http://www.nccarf.edu.au/conference2010/ wp-content/uploads/Syed-Mohazri-Syed-Hazari.pdf (accessed 5 May 2011).

Murty, T. (1977) 'Seismic sea waves - tsunamis'Bull. Dept. Fisheries, Canada.

Nadim, F. and Glade, T. (2006) 'On tsunami risk assessment for the west coast of Thailand', in Nadim, F., Pöttler, R., Einstein, H., Klapperich, H. and Kramer, S. (Eds.): ECI Symposium Series 7 [online] http://services.bepress.com/eci/geohazards/28 (accessed 2 July 2015).

New Straits Times (2007) [online] http://findarticles.com/p/news-articles/ new-straits-times/mi_8016/is_20070910/800-flood-victims-return-home/ai_n44375213/ (accessed 5 May 2011).

NGI (2006) Tsunami Risk Reduction Measures with Focus on Land Use and Rehabilitation, NGI-report 20051267-1 [online] .http://www.ngi.no/en/Contentboxes-and-structures/ Reference-Projects/Reference-projects/The-Risk-of-Tsunamis-in-Southeast-Asia/ (accessed 2 July 2015).

NGI (2009a) Global Risk Update: Global Hazard and Risk Due to Tsunamis Generated By Large Earthquakes - Results From First Pass Analyses, NGI-report 20081087-1 [online] http://www.preventionweb.net/english/hyogo/gar/report/ (accessed 2 July 2015).

NGI (2009b) Risk Assessment and Mitigation Measures for Natural-and Conflict-Related Hazards in Asia-Pacific, NGI-report 20071600-1.

NGI (2011a) Assessment of Exposure to Natural Hazards: Phase A - Preliminary Assessment of Natural Hazards, NGI-report 20110365-00-2-R.

NGI (2011b) Volcano Hazard and Exposure in GFDRR Priority Countries and Risk Mitigation Measures, NGI-report 20100806.

NGI (2014a) Sammenligning av risikoakseptkriterier for skred og flom: Utredning for Naturfareprogrammet (NIFS), NGI-report 20130800-01-R, in Norwegian.

NGI (2014b) Institutional Support and Human Resource Development in Mitigation of Geohazards in India: Tsunami Hazard Assessment for Tamil Nadu - The Chennai and Nagapattinam Cases, NGI-report 20091887-00-5-R.

Nicholls, R.J. and Cazenave, A. (2010) 'Sea-level rise and its impact on coastal zones', Science, Vol. 328 , No. 5985, pp.1517-1520. 
Nicholls, R.J., Wong, P.P., Burkett, V.R., Codignotto, J.O., Hay, J.E., McLean, R.F., Ragoonaden, S. and Woodroffe, C.D. (2007) 'Coastal systems and low-lying areas', Climate Change 2007: Impacts, Adaptation and Vulnerability, pp.315-356, Cambridge University Press, Cambridge.

Paris, R., Switzer, A.D., Belousova, M., Belousov, A., Ontowirjo, B., Whelley, P.L. and Ulvrova, M. (2014) 'Volcanic tsunami: a review of source mechanisms, past events and hazards in Southeast Asia (Indonesia, Philippines, Papua New Guinea)', Nat Hazards, Vol. 70, No. 1, pp.447-470, doi: 10.1007/s11069-013-0822-8.

Pedersen, G. and Løvholt, F. (2008) Documentation of a Global Boussinesq Solver: Mechanics and Applied Mathematics, February, Vol. 1, ISSN 0809-4403, Dept. of Mathematics, University of Oslo, Norway [online] http://www.duo.uio.no/publ/matematikk/2008/124495/ mech-01-08.pdf (accessed 2 July 2015).

Peiser, R. and Frej, A.J. (2003) Professional Real Estate Development: The ULI Guide to the Business, 2nd ed., ULI - the Urban Land Institute, Washington, DC.

Pelinovsky, E., Choi, B.H., Stromkov, A., Didenkulova, I. and Kim, H-S. (2005) 'Analysis of tide-gauge records of the 1883 Krakatau Tsunami', in Satake, K. (Ed.): Tsunamis: Case Studies and Recent Developments, Advances in Natural and Technological Hazards Research 23, Tsunamis, Part I, pp.57-77.

Peltier, W. (2000) 'Global glacial isostatic adjustment and modern instrumental records of relative sea level history', in Douglas, B.C., Kearny, M.S. and Leatherman, S.P. (Eds.): Sea Level Rise; History and Consequences, pp.65-95, Academic Press, San Diego.

Petoukhov, V., Ganopolski, A., Brovkin, V., Claussen, M., Eliseev, A., Kubatzki, C. and Rahmstorf, S. (2000) 'CLIMBER-2: a climate system model of intermediate complexity: part I: model description and performance for present climate', Climate Dynamics, Vol. 16, No. 1, pp.1-17.

Rahmstorf, S. (2010) 'A new view on sea level rise', Nature Reports Climate Change, Vol. 4, No. 4, pp.44-45, doi:10.1038/climate.2010.29.

Roseli, M. (1999) Hydrological and Hydraulic Sensitivity Analyses for Flood Modelling With Limited Data, PhD thesis, University of Birmingham, Birmingham, UK.

Samsung (2011) Samsung Begins Operation of World's Largest Memory Fab, Press Release, 22 September [online] http://www.samsungvillage.com/blog/2011/09/ samsungblog-samsung-begins-operation-of-worlds-largest-memory-fab.html (accessed 1 March 2015).

Schmidt, J., Matcham, I., Reese, S., King, A., Bell, R., Henderson, R., Smart, G., Cousins, J., Smith, W. and Heron, D. (2011) 'Quantitative multi-risk analysis for natural hazards: a framework for multi-risk modelling', Natural Hazards, Vol. 58, No. 3, pp.1169-1192, doi:10.1007/s11069-011-9721-z.

Schwab, J.M., Krastel, S., Grün, M., Gross, F., Pananont, P., Jintasaeranee, P., Bunsomboonsakul, S., Weinrebe, W. and Winkelmann, D. (2012) 'Submarine mass wasting and associated tsunami risk offshore western Thailand, Andaman Sea, Indian Ocean', Nat. Hazards Earth Syst, Sci., Vol. 12, No. 8, pp.2609-2630, doi:10.5194/nhess-12-2609-2012.

Simkin, T. and Fiske, R.S. (1983) Krakatau 1883 - The Volcanic Eruption and Its Effects. Smithsonian Institution Press, Washington, DC.

Soloviev, S.L. and Go, C.N. (1974) A Catalogue of Tsunamis on the Western Shore of the Pacific Ocean, 439pp, Academy of Sciences of the USSR, Nauka Publishing House, Moscow.

Symons, G.J. (Ed.) (1888) The Eruption of Krakatao and Subsequent Phenomena, Report of the Krakatao committee of the Royal Society, London. Trubner \& Co.

Synolakis, C.E. and Kong, L. (2006) 'Runup measurements of the December 2004 Indian Ocean tsunami', Earthquake Spectra, Vol. 22, No. S3, pp.S67-S91.

Vafeidis, A.T., Boot, G., Cox, J., Maatens, R., McFadden, L., Nicholls R.J., Spencer, T. and Tol, R.S.J (2006) The DIVA Database Documentation. 
Vafeidis, A.T., Nicholls, R.J., McFadden, L., Tol, R.S.J., Hinkel, J., Spencer, T., Grashoff, P.S., Boot, G. and Klein, R.J.T. (2008) 'A new global coastal database for impact and vulnerability analysis to sea-level rise', Journal of Coastal Research, Vol. 24, No. 4, pp.917-924.

van Oldenborgh, G.J., Collins, M., Arblaster, J., Christensen, J.H., Marotzke, J., Power, S.B., Rummukainen, M. and Zhou, T. (Eds.) (2013) 'Annex I: Atlas of global and regional climate projections', in Stocker, T.F., Qin, D., Plattner, G-K., Tignor, M., Allen, S.K., Boschung, J., Nauels, A., Xia, Y., Bex, V. and Midgley, P.M. (Eds.): Climate Change 2013: The Physical Science Basis. Contribution of Working Group I to the Fifth Assessment Report of the Intergovernmental Panel on Climate Change, pp.1311-1394, doi:10.1017/CBO9781107415324.029, Cambridge University Press, Cambridge, UK and New York, NY, USA.

Verbeek, R.D.M. (1885) Krakatau, Batavia, Landsdrukkerij.

Vermeer, M. and Rahmstorf, S. (2009) 'Global sea level linked to global temperature', in Proceedings of the National Academy of Sciences, Vol. 106, No. 51, pp.21527-21532.

von Storch, H. and Woth, K. (2008) 'Storm surges: perspectives and options', Sustain Sci., Vol. 3, No. 1, pp.33-43, doi:10.1007/s11625-008-0044-2.

Wolf, J. (2009) 'Coastal flooding: impacts of coupled wave-surge-tide models', Natural Hazards, Vol. 49, No. 2, pp.241-260, doi:10.1007/s11069-008-9316-5.

Yalciner, A.C., Ghazali, N.H. and Abd-Wahab, A.K. (2005) IO Tsunami Field Survey at North West Peninsular Malaysian Coast, 26 December 2004, Middle East Technical University Report.

Yeh, H., Imamura, F., Synolakis, C., Tsuji, Y., Liu, P. and Shi, S. (1993) 'The Flores Island tsunami', Eos, Transactions, American Geophysical Union, Vol. 74, No. 33, p.369, pp.371-373.

\section{Notes}

1 The paper by Megawati et al. (2005) was accepted before the 26th December 2004 Sumatra earthquake with its epicentre located at $3.316^{\circ} \mathrm{N} 95.854^{\circ} \mathrm{E}$. 